\title{
Consequences on Consumption of Packaged Drinking Water
}

\author{
S. Archana Bai, T. Vimala
}

\begin{abstract}
This empirical study was conducted to examine the consequences on consumption of packaged drinking water among the consumers residing in Chennai city. Descriptive and empirical research design was adopted to gather primary information from the packaged drinking water consumers by employing non-probability convenience sampling. The primary data collected were analysed with the help of various statistical tools through PSPP software in present study. The results indicate that consumers are often exposed to various health issues due to the consumption of packaged drinking water in their day-to-day life. Fitness and Safety, Aid \& Supply, Usefulness and Economic factors are the major components significantly influencing the consumer perception towards purchase decision and consumption behavior. To conclude, public health department should take the actions by visit the packaged drinking water plant area and also check the quality of water. It should be prevented to avoid the duplicate sachets of water which causes more health diseases to regular consumers.
\end{abstract}

Keywords : Packaged Drinking Water, Consequences, Health, Safety and Consumption.

\section{INTRODUCTION}

$\mathrm{W}$ orld Health Organization (WHO) appraisal proves that above 4 million children are died from the diarrhea and fever which can be bottled up by unhealthy water. Many developed countries water is not only a basic usage food, but also a life style product(Murray \&et. al., 1996). In many countries, due to non-availability of sufficient and portable water facility in all the places water was contaminated due to various reasons. The packaged drinking water are filled in sealed containers in various quantities, forms and capacity for the direct consumption of consumers. This packaged drinking water should pass the treatment process conducted by Food Safety and Standards Authority of India rules and grade quality to reach the consumers of India. According to Consumer Voice Survey 2017, Rail Neer is the top performer followed by Mcdowell's and Bisleri based on the result generated in microbiological test. Rail Neer considered as the value-for-money brand because of its pricing strategy. The mineral water was chemically retreated to convert as a packaged drinking water. Packaged drinking water is unhealthy and shorter shelf of life as compared to mineral

Revised Manuscript Received on December 05, 2019.

* Correspondence Author

Dr. S. Archana Bai*, Assistant Professor, Department of Commerce, Sir Theagaraya College, Chennai, Tamil Nadu, India

Dr. (Mrs).T. Vimala, Assistant Professor, Department of Commerce, Quaid-E-Millath Government College for Women (Autonomous) Chennai, Tamil Nadu, India. water. The world wide has increased significantly in usage of bottled mineral water and it also become an important both factor for economic and health issues (Doria, 2006; Whelton \& et. al., 2007). Natural mineral water means rising in underground water arising from the spring tapped at more natural, bore exits (Hunter, P. R. 1993; Stickler, 1989; LaMoreaux, \&Tanner, 2001; Varga, 2011; Falcone-Dias \& et. al., 2012; Moazeni \& et. al., 2014). Bottled water has been marketed as a perfect for instant formula preparation, particularly for the immune- suppressed people. There are several insufficient clinical and epidemiological witness to conclude that the high heterotrophic counts in drinking water pose a risk to a consumers' health (Cisneros, \& Rose, 2009; WHO, 2011). Nevertheless, some people can cause the diseases with the bottled water mainly among sensitive persons, like the young, the elderly, the immune suppressed population, and pregnant women.

\section{PACKAGED DRINKING WATER DIVERSE FACTORS}

Health: While consuming the packaged drinking water is safe and clean. The consumers are feel confident to consumed it due to the packed in a hygienic way. We discussed about the packaged drinking water because it advised by doctors and also since it has the better quality of packaged drinking water (Larson,\& Gnedenko, 1999; Colford, \&et. al., 2006).

Availability: In this study the perception of anyone is decided to the availability of the packaged drinking water in the market. There are plenty of opportunities are available, when the sufficient number of good branded and good quality and different quantities are available in packaged drinking water. Here there also the credit facilities are provided by the suppliers and it also available at free door delivery (Chapman, 1996; Wilkins, 1994).

Price: Here, the availability of packaged drinking water at reasonable price into the consumers. Its price should be fits into their family budget with the lowest deposit of initial amount for packaged drinking water (Güler, 2007). The bulk of packaged drinking water got some discount amount and during the time of shortage period, the suppliers would increased the packaged drinking waters' amount.

Service and Packaging: In this study the services are good from suppliers by the right time. The packaged drinking water is conveniently provided by anyone and anywhere. The consumers feels good to consumption of packaged drinking water has a good brand image and tight sealed packs 


\section{Consequences on Consumption of Packaged Drinking Water}

(Klimchuk, \& Krasovec, 2013;Verghese, \&et. al., 2015; Ambrose, \& Harris, 2017).

So the consumers may recommend this packaged drinking water to others as they are safer than other drinking water.

\section{REVIEW OF LITERATURE}

Doria and et al., (2009) examined the perceptions of consumers with respect to the quality and risk on the behavioural influence in the UK and Portugal. The researchers has applied the cross sectional research design to gather qualitative information through focus group interviews. The structural equation model was applied to examine the diverse factors influence on consumer behavior. The result indicates that risk, colour, flavor, quality and trust are the significant factors influencing the consumer behavior towards the consumption of packaged drinking water. The researchers suggested to adopt European-wide standards for human consumption of drinking water.

Doria (2009) conducted an empirical study to examine the factors determining the public perception towards drinking water quality in France. This study was aimed to contribute through public perception for the improvement and enhancement in the water management system, delivery of indicates that flavor is the most important factor influencing the quality of drinking water. In addition, water managers and policy makers are suggested to take necessary steps to overcome the potential problems and also to maintain the quality standards. Further, Doria (2011) states that the consumption of packaged drinking water was noted as high even though the quality of tap water is high in many developed countries. Further, the author also stressed that dissatisfaction on tap water and health concerns are the major factors influence public behavior.

Ogbuji and et al., (2011) conducted an empirical study to examine the Nigerians perception towards the branding of regulated bottled water in the regular consumption. The result of the empirical evidences proves that branding as a marketing strategy influences the consumer behaviour towards consumption of bottled water in Nigeria.

Sumathy (2015) has the aim of the study is to examined the Domestic Ro water and its consumers perception in District. The investigator stated the problems have made people to seek the various water treatment equipment. The researcher found that the attributes related to usage, installation and to purpose of using treated $\mathrm{RO}$ water and utilization of waste water. The researcher likes to identify the variations and to given the promotion policies to leverages, to achieved optimum benefits. It also provided the educate consumers about the various mode of using the waste water usefully. Then finally concluded, with that drinking water is becomes a scares and expensive commodity with increasing contaminants in making filter is essential and RO water treatment plant is badly needed in the presented study area.

\section{STATEMENT OF PROBLEM}

The consumption of unsafe drinking water, are containing consumer services and reuse intention. The test result

with the poor water quality and cleanliness are the main subscribers to supposed the some billions cases of diarrheal diseases are yearly, causing above one million deaths, and monthly in the middle of 5years of age. The consumption water has huge quantities in this world. The risk of health should associated with the consumption of harmful water is of greatest concern. The sarcastic question is "why the health-based diseases are high in our India, still the consumers are using the packaged drinking water which is stocked in usual and hygienic manner at home?". Therefore the analyzer has made an attempt to find out the actual awareness of consumers towards consuming the packaged drinking water in Chennai City. The study research questions are How for the consumers aware on the packaged drinking water consumption diseases?.What are the health issues identified while consuming the packaged drinking water and evaluate the consumers opinions?.

\section{SCOPE OF THE STUDY}

The current study attempts to examine the socioeconomic status and usage profile of packaged drinking water of the respondents to understand the life span of the population in the study area. It examines the consumers' awareness, preference and perception and health issues towards packaged drinking water. Further it examines the opinions about the packaged drinking water consumption and determinants of dimensions of the packaged drinking water consumption by the consumers based on their selected socioeconomic status. The present study is from the standard point of the consumers' awareness of packaged drinking water in the Chennai City.

\section{OBJECTIVES OF THE STUDY}

The major aim of the present study is to explore the consequences on consumption of packaged drinking water and also to study the consumers' awareness on packaged drinking water consumption diseases and determine the dimensions of packaged drinking water consumption.

\section{METHODOLOGY}

Methodology adopted for the study; primary data was collected by in-depth interview of the respondents through structured questionnaire. The survey questionnaire started with respondents demographic profile and ended with variable specific Questions related to consumers perception towards packaged drinking water, followed by the questions measuring the opinion of packaged drinking water consumption, a ranking question regarding the situation of consumers consumes package drinking water, multiple response regarding packaged drinking water brand preference followed by variables measuring the dimension of consumers packaged drinking water consumption on consumers opinion about the packaged drinking water were asked through a five point Likert scale where 1 stands for 
"strongly disagree", 5 stands for "strongly agree". The sample size was 223 and convenience sampling technique had been used to collect the primary data from respondents. After the data has been collected, it was processed using Microsoft Excel for coding and SPSS version 23.0 software package was used for the following analysis.

\section{RESULTS AND DISCUSSION}

\section{Table 1: Demographic Profile of Packaged Drinking Water Consumers}

Demographic Profile $(\mathrm{N}=223)$

\section{Age}

Between 15 to 25 Yrs

Between 26 to 35 Yrs

Between 36 to 45 Yrs

Above 46 Yrs

\begin{tabular}{|c|c|c|}
\hline \multicolumn{3}{|l|}{ Gender } \\
\hline Male & 104 & 46.6 \\
\hline Female & 119 & 53.4 \\
\hline \multicolumn{3}{|l|}{ Educational Status } \\
\hline School level & 15 & 6.7 \\
\hline Graduate & 124 & 55.6 \\
\hline Post - Graduate & 59 & 26.5 \\
\hline Professional and Others & 25 & 11.2 \\
\hline
\end{tabular}

\section{Occupation}

Self Employed

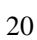

Salaried

House Wife

Others

\section{Monthly Income Level}

Below Rs. 10,000

Rs. 10,000 - Rs. 30,000

Rs.30,000 - Rs.60,000

Above Rs.60,000

\section{Area of living}

Urban

Semi - Urban

Family Type

Nuclear Family

Joint Family

94

57.8

42.2

\begin{tabular}{cc|c} 
Marital Status & & \\
Married & 95 & 42.6 \\
Un Married & $\mathbf{1 2 8}$ & $\mathbf{5 7 . 4}$
\end{tabular}

The above results reveals that the 223 respondents,
Majority of the respondents are Female 53.4\%, 55.6\% of the respondents belongs to the age group of $15-25,55.6 \%$ of the respondents are Graduates, $57.4 \%$ of the respondents are Unmarried, $51.6 \%$ of the respondents are Salaried persons, $42.6 \%$ of the respondents get Monthly Income is Below Rs. $10,000,77.6 \%$ of the respondents are living in Urban area, and $57.8 \%$ of the respondents Family is Nuclear type.

Table 2: Consumer Perception on Packaged Drinking Water Consumption

Consumer Perception on Packaged Drinking Water Frequency Percent
Consumption

How often do you drink Packaged Drinking Water (PDW)?

Every day

35.0

3-5 Times a Week

10.3

Once a week

13.9

Occasionally

40.8

Quantum of Packaged Drinking Water Consume?

Below $500 \mathrm{ml}$

31.4

$500 \mathrm{ml}$ to $1 \mathrm{ltr}$

19.3

1 ltr to 2 ltrs

18.8

2 ltr to 5 ltrs

18.4

5 ltr to 20 ltrs

How long you have been consuming Packaged Drinking

Water?

Recently 5 Months Before

35.0

1 Year Back

17.0

1 to 3 Years Back

20.6

More than 3 years Back

27.4

What is the frequency of buying Packaged Drinking

Water per month?

Below 5 times

50.2

6 to 10 Times

23.3

10 to 15 times

18.4

More than 15 times

8.1

The feel after consuming the Packaged Drinking Water regards your health condition?

$\begin{array}{lll}\text { Good } & 79 & 35.4 \\ \text { Safe } & 29 & 13.0 \\ \text { Some Affects } & 31 & 13.9 \\ \text { Don't know } & \mathbf{8 4} & \mathbf{3 7 . 7}\end{array}$

The effects of frequent usage of Packaged Drinking

Water?

Improves Health

14.8

Affects the health

25.6

Don't know

57

59.6

How much amount you spent for consumption of PDW per month?

Less than Rs.500

65.0

Rs. 501 to Rs. 1000

47

21.1

Rs. 1001 to Rs. 1500

11.2 


\section{Consequences on Consumption of Packaged Drinking Water}

Above Rs. 1501

6

2.7

The consumer perception of packaged drinking water is, $40.8 \%$ of the consumers are often to drink Occasionally, and $31.4 \%$ of the consumers are consumed the packaged drinking water Quantum is Below 500ml per day. 35\% of the consumers consumed the packaged drinking water' during level is in Recently 5 Months before.

The frequency of the buying packaged drinking water per month is only Below times on the percentage of $50.2 \%$, $37.7 \%$ of the consumers they don't know about feet of their health condition by after consumption of packaged drinking water, and also $59.6 \%$ of the consumers don't know about their frequent usage of packaged drinking water's effects after the consumption, and $65 \%$ of the consumers are spent the amount is less than Rs.500 for the consumption of packaged drinking water per month.

Table 3: Health Issues while consuming the Packaged Drinking Water

\begin{tabular}{|c|c|c|c|c|}
\hline $\begin{array}{l}\text { Health Issues while consuming the } \\
\text { Packaged Drinking Water }\end{array}$ & Mean & $\begin{array}{c}\text { Std. } \\
\text { Deviation }\end{array}$ & $\begin{array}{c}\text { Skewness } \\
\qquad \begin{array}{c}\text { (S.E = } \\
\text { 0.163) }\end{array}\end{array}$ & $\begin{array}{c}\text { Kurtosis } \\
\text { (S.E = } \\
\text { 0.324) }\end{array}$ \\
\hline Fever & 1.87 & 1.035 & .936 & -.080 \\
\hline Stomach Upset & 1.82 & .999 & .924 & -.042 \\
\hline Vomiting & 1.56 & .947 & 1.604 & 1.605 \\
\hline Headache & 1.77 & 1.018 & 1.284 & 1.102 \\
\hline Allergy & 1.63 & 1.004 & 1.464 & 1.255 \\
\hline Diarrhea & 1.54 & .952 & 1.629 & 1.617 \\
\hline Tooth decay and Gum damage & 1.70 & 1.055 & 1.417 & 1.161 \\
\hline Diabetes & 1.34 & .771 & 2.596 & 6.757 \\
\hline Obesity & 1.51 & .981 & 1.946 & 2.984 \\
\hline Typhoid & 1.70 & 1.096 & 1.398 & .965 \\
\hline
\end{tabular}

The descriptive statistics result reveals that among the Health issues of the consumers while consuming the packaged drinking water. A total of 223 respondents, mean values are seen, 1.87 most of the consumers are suffering Fever while consuming are suffered by the stomach upset.
The balance of the consumers are also have the lots of health issues are, 1.77 of suffering with Headache and 1.70 of suffering with the Tooth Decay, and Typhoid. They also have the Allergy is 1.63, Vomiting 1.56, Diarrhea is 1.54, Obesity is 1.51 , and 1.34 of the consumers suffered by Diabetes

\section{DETERMINANTS OF PACKAGED DRINKING WATER CONSUMPTION ON CONSUMER OPINIONS}

The consumer opinion on packaged drinking water consumption (dependent variable) might be predicted from dimension of packaged drinking water consumption with respect to fitness \& safety, aid \& supply, usefulness and economic (independent variables).

The multiple regression ordinal least square empirical result indicates $\mathrm{R}=0.842$, $\mathrm{R}$ Square $=0.709$, Adjusted $\mathrm{R}$ square $=$ 0.705 , Std. Error of the estimate $=7.123$. This implies that the independent variables with respect to Fitness and Safety, Aid \& Supply and Usefulness create $70.9 \%$ influence over the dependent factor of consumers' opinion of packaged drinking water consumption with respect to kind of product, protection from harm, convenient and support. This leads to further verification of the regression fit as stated in the ANOVA table. Also found that $\mathrm{F}=177.520$ and $\mathrm{p}<0.01$ are statistically significant at the 5\% level. Therefore it is concluded that independent variables with respect to dimensions of packaged drinking water consumption are good enough to have an explorative power of consumers prefer packaged drinking water.. The good regression fit indicates the existence of individual influence over the dependent factors with respect to dimensions of packaged drinking water such as Fitness and Safety, Aid \& Supply and Usefulness. From the table it is explore the Coefficients result value of Fitness and Safety $(t=10.152, \beta=0.592, p<0.01)$, Aid \& Supply $(\mathrm{t}=2.953, \beta=0.176, \mathrm{p}<0.01)$ and Usefulness $(\mathrm{t}=3.136, \beta=0.153, \mathrm{p}<0.01)$ are statistically significant at $5 \%$ level.

Table 4: Determinants of Packaged Drinking Water Consumption on Consumer Opinions

\begin{tabular}{|c|c|c|c|c|c|c|c|c|c|c|c|}
\hline \multirow{2}{*}{ Dependent Variable } & \multirow{2}{*}{$\begin{array}{l}\text { Significant } \\
\text { Predictors }\end{array}$} & \multirow{2}{*}{$\begin{array}{l}\text { No. of } \\
\text { Items }\end{array}$} & \multirow{2}{*}{ Mean (SD) } & \multirow{2}{*}{ F-Value } & \multirow{2}{*}{$\mathbf{R}$} & \multirow{2}{*}{$\mathbf{R} 2$} & \multirow{2}{*}{$\begin{array}{c}\text { Adjusted } \\
\text { R2 }\end{array}$} & \multirow{2}{*}{$\beta$ (t-Value) } & \multirow{2}{*}{ Sig. } & \multicolumn{2}{|c|}{ Collinearity Statistics } \\
\hline & & & & & & & & & & Tolerance & VIF \\
\hline \multirow[t]{2}{*}{ Consumer Opinions } & & 18 & $53.70(13.11)$ & $\begin{array}{l}177.52 \\
(0.000)\end{array}$ & $\begin{array}{c}0.84 \\
2\end{array}$ & $\begin{array}{c}0.70 \\
9\end{array}$ & 0.705 & & & & \\
\hline & $\begin{array}{l}\text { Fitness and } \\
\text { Safety }\end{array}$ & 9 & $28.22(7.506)$ & & & & & $\begin{array}{c}0.592 \\
(10.152)\end{array}$ & $<0.001 * *$ & 0.391 & 2.555 \\
\hline & Aid \& Supply & 8 & $25.65(6.619)$ & & & & & $\begin{array}{c}0.176 \\
(2.953)\end{array}$ & $\begin{array}{l}<0.003 \\
* *\end{array}$ & 0.373 & 2.681 \\
\hline
\end{tabular}




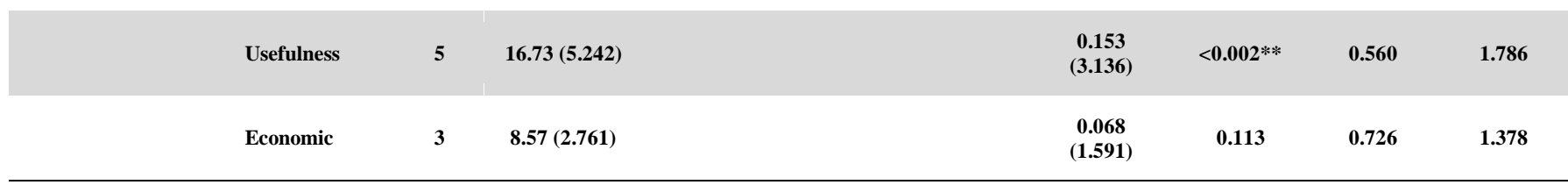

Constant with $\mathrm{t}$ value of 9.181 at $\mathrm{P}$ Value of $<0.001 *$ - (Economic was not significant influencing the customer opinion towards packaged drinking water)

Notes: *** Significant @ 1\% level, *Significant @ 5\% Level.

Furthermore, there is an insufficient influence of consumers opinion packaged drinking water consumption by economic $(t=1.591, \beta=0.068, p>0.01)$ are not significant at 5\% level. Therefore it is concluded that dimensions of packaged drinking water consumption with respect to Fitness and Safety, Aid \& Supply and Usefulness highly influences of consumers' opinion of packaged drinking water consumption.

\section{IMPLICATION AND CONCLUSION}

- The respondents should check the information on the packaged drinking water labels clearly. Because, it is the nature of perishable. So the manufacturer should given the clear visible information of the manufacturing date, expiry date and other information of the packaged drinking water.

- Only the few consumers feel the positive consumption as they are germs free. So, consumers should need to know about the usage consequences, life and chemical aspects of packaged drinking water.

- The respondents have no idea about the effects of packaged drinking water. When they consumed the packaged drinking water, they suffered lots from Health issues of fever, typhoid, vomiting, diarrhea, etc., So, the consumers should have awareness on the consumption of packaged drinking water and its positive and negative effects on the health.

- The Health department should take the actions by visit the packaged drinking water plant area and also check the quality of water. It should be prevented to avoid the chemically treated water which is not suitable for regular human consumption.

The packaged drinking water was playing a substantial role into the society, because, the lack of the clean drinking water. In this study, the majority of the consumers have no adequacy awareness of the packaged drinking water issues. They do not know about the effects of the packaged drinking water while they consumed. The respondents do not given any complaints against the lesser quality of packaged drinking water with written way. They give only oral complaints to the retailers. But the retailers did not give any importance to their complaints and simply they ignored it. Because, of their increase profit. The consumers should check the other information on the packaged drinking water and also check the manufacturing date, expiry date, and ISI mark and other information also. To immediately inform the Health department if any problems are rises means. The Health department also should take steps to the complaints

about packaged drinking water and also should regulate the production and sales. Majority of the consumers consumed the packaged drinking water while during travel time. Too much consumption of packaged drinking water also affects the health. The packaged drinking water's details must be printed in a visible way clearly, and the Food and Drug Administration department should take a surprise visit to production and sales plant to make secure the quality of packaged drinking water. The people still not having the aware source of life (water). Therefore the government and manufacture should improve the awareness of the people through media like Television, Radio, Advertisement and other way like Pamphlets, Balloons, etc.,. The government should also give the awareness about the issues related to packaged drinking water consumption through social advertisements.

\section{REFERENCES}

1. Ambrose, G., \& Harris, P. (2017). Packaging the brand: the relationship between packaging design and brand identity. Bloomsbury Publishing.

2. Chapman, D. V. (Ed.). (1996). Water quality assessments: a guide to the use of biota, sediments and water in environmental monitoring. CRC Press.

3. Cisneros, B. J., \& Rose, J. B. (2009). Urban water security: managing risks: UNESCO-IHP. CRC Press.

4. Colford, J. M., Roy, S., Beach, M. J., Hightower, A., Shaw, S. E., \& Wade, T. J. (2006). A review of household drinking water intervention trials and an approach to the estimation of endemic waterborne gastroenteritis in the United States. Journal of water and health, 4(S2), 71-88.

5. de França Doria, M. (2010). Factors influencing public perception of drinking water quality. Water policy, 12(1), 1-19.

6. de França Doria, M., Pidgeon, N., \& Hunter, P. R. (2009). Perceptions of drinking water quality and risk and its effect on behaviour: A cross-national study. Science of the Total Environment, 407(21), 5455-5464.

7. Doria, M. F. (2006). Bottled water versus tap water: understanding consumers' preferences. Journal of water and health, 4(2), 271-276.

8. Falcone-Dias, M. F., Vaz-Moreira, I., \& Manaia, C. M. (2012). Bottled mineral water as a potential source of antibiotic resistant bacteria. Water research, 46(11), 3612-3622.

9. Güler, C. (2007). Evaluation of maximum contaminant levels in Turkish bottled drinking waters utilizing parameters reported on manufacturer's labeling and government-issued production licenses. Journal of Food Composition and Analysis, 20(3-4), 262-272.

10. Hunter, P. R. (1993). The microbiology of bottled natural mineral waters. Journal of Applied Bacteriology, 74(4), 345-352.

11. Klimchuk, M. R., \& Krasovec, S. A. (2013). Packaging design: Successful product branding from concept to shelf. John Wiley \& Sons.

12. LaMoreaux, P. E., \& Tanner, J. T. (2001). Springs and bottled waters of the world: ancient history, source, occurrence, quality and use. Springer Science \& Business Media.

13. Larson, B. A., \& Gnedenko, E. D. (1999). Avoiding health risks from drinking water in Moscow: An empirical analysis. Environment and Development Economics, 4(4), 565-581.

14. Moazeni, M., Ebrahimi, A., Atefi, M., Mahaki, B., \& Rastegari, H. A (2014). Determination of nitrate and nitrite exposure and their health risk assessment in 21 brands of bottled waters in Isfahan's market in 2013 International Journal of Environmental Health Engineering, 3(1), 28.

15. Murray, C. J., Lopez, A. D., \& World Health Organization. (1996). The global burden of disease: a comprehensive assessment of mortality and disability from diseases, injuries, and risk factors in 1990 and projected to 2020: summary. 


\section{Consequences on Consumption of Packaged Drinking Water}

16. Ogbuji, C. N., Anyanwu, A. V., \& Onah, J. O. (2011). An empirical study of the impact of branding on consumer choice for regulated bottled water in southeast, Nigeria. International Journal of Business and Management, 6(6), 150-66.

17. Stickler, D. J. (1989). The microbiology of bottled natural mineral waters. Journal of the Royal Society of Health, 109(4), 118-124.

18. Sumathy, V. G. (2015). Consumers' Perception Towards Domestic RO Water Treatment Plant in Erode District. International Journal of Business and Administration Research Review, 1(12), 218-224.

19. Varga, L. (2011). Bacteriological quality of bottled natural mineral waters commercialized in Hungary. Food Control, 22(3-4), 591-595.

20. Verghese, K., Lewis, H., Lockrey, S., \& Williams, H. (2015). Packaging's role in minimizing food loss and waste across the supply chain. Packaging Technology and Science, 28(7), 603-620.

21. Whelton, A. J., Dietrich, A. M., Burlingame, G. A., Schechs, M., \& Duncan, S. E. (2007). Minerals in drinking water: impacts on taste and importance to consumer health. Water Science and Technology, 55(5), 283-291.

22. Wilkins, M., Jones, G., \& Morgan, N. (1994). When and why brand names in food and drink?. Adding value: brands and marketing in food and drink, $15-40$.

23. World Health Organization. (2011). Technical guidance on water-related disease surveillance. 